\title{
Diverse Approaches to Herbicide-Resistant Weed Management
}

\begin{abstract}
Micheal D. K. Owen*
Herbicides have been the principal means of weed control in developed countries for approximately $50 \mathrm{yr}$ because they are the most cost-effective method. Such general use of herbicides has resulted in weed resistance to herbicides, which continues to be a growing problem. Within the past decade, the evolution of resistance to the once-dominant herbicide glyphosate has resulted in major concerns about the future ability to control weeds in many crop systems. Moreover, many weed species have evolved resistance to multiple mechanisms of herbicide action. Given the dearth of new herbicides with novel mechanisms of action, it appears inevitable that weed management programs will need to be supplemented by the use of tactics other than herbicides. However, the inclusion of more diversity for weed management also introduces complexity, cost, and time constraints to current crop production systems. This paper describes broadly the considerations, opportunities, and constraints of diverse weed management tactics to address the burgeoning problems with herbicide resistance.
\end{abstract}

Key words: Diversity, herbicide resistance, strategies, tactics, weed management.

Weeds are the most important pest complex that globally reduces the ability of mankind to produce food, fiber, and fuel (Oerke 2006). Weeds have always been a component of agriculture and have successfully thwarted all attempts by humans to eliminate them from interfering with crop production (Baker 1991; Vigueira et al. 2013). Over the last several decades, weed adaptations to management tactics, including biochemical mimicry in the form of evolved resistance to the herbicides used for weed control, have increased rapidly throughout agriculture and now threaten global food security (Delye et al. 2013; McElroy 2014). There are also concerns as to whether agricultural weed research efforts have been sufficiently robust, diverse, and integrated to address herbicide resistance and other evolving weed issues (Ward et al. 2014).

From a general perspective, the principles of weed management have not changed appreciably in more than a century (Buhler et al. 2000; Harvey 1991; Norsworthy et al. 2012; Wooton 1894). Weed management approaches are broadly categorized as biological, cultural, herbicidal, and mechanical. Generally, there have not been new approaches to weed management since the introduction and adoption of herbicides as the primary tactic to address weed control in developed countries. It could be argued that the development of crops with genetically engineered (GE) resistance to herbicides

\footnotetext{
DOI: $10.1614 /$ WS-D-15-00117.1

* University Professor, Agronomy Department, Iowa State University, Ames, IA 50011. Corresponding author's E-mail: mdowen@iastate.edu
}

is a novel strategy, although when considered pragmatically, this technology is still a herbicidebased tactic and thus does not represent a "new" approach (Owen 2012). Over the last four decades, the integration of tactics for weed management has become less of a concern, resulting in simple and convenient weed control programs lacking in diversity and-some would argue-sustainability (Davis et al. 2009; Stern et al. 1959; Swanton et al. 2008; Zalucki et al. 2015). As the complexity of issues facing agriculture increases as illustrated by the burgeoning global population, climate change, and the increasing evolution of herbicide resistances in weeds, the social, economic, and environmental concerns of the lay public about agricultural intensification, as well as political pressures at the state, federal, and global levels suggest an immediate need to objectively assess these problems. Weed management, and specifically herbicide management, should reflect the importance of integrated and sustainable approaches to control the most important pest complex and thus better support global food production (Davis et al. 2009; Duke and Powles 2009; Hails 2005; Vasileiadis et al. 2013). The goal of this paper is to address the options available for robust integrated weed management, specifically the management of herbicideresistant (HR) weeds, and assess the benefits and risks of tactics that contribute to more diverse approaches. In this context, the author will use the concept of "diversity" to focus on nonherbicidal weed management tactics. 


\section{Considerations about Herbicide-Resistant Weeds}

Although most people who are not weed scientists - and perhaps even some weed scientists-believe that herbicide resistance and glyphosate resistance are synonymous, herbicide resistance has long been recognized as a problem attributable to herbicide use (Harper 1956). There have been three major evolutionary "events": resistance to WSSA Group 5 (photosystem II inhibitor herbicides) was first reported in 1970, followed by WSSA Group 2 (acetolactate synthase [ALS] inhibitor herbicides) resistance in 1982, and again in 1996 with WSSA Group 9 (enzyme 5enolpyruvylshikimate 3-phosphate synthase-inhibitor herbicide) resistance (Heap 2015). For each of these herbicide groups, it took some additional time before a major agronomic impact in most crop systems was recognized, and most other herbicide groups now have weed biotypes with evolved resistance(s) in many economically important weed species (Heap 2015). The evolution of WSSA Group 9 resistance was a major factor given the unprecedented global adoption of glyphosate-resistant (GR) crop cultivars (Powles 2008). Glyphosate-resistant weeds have caused farmers, the agricultural chemical and seed industries, commodity organizations, and regulatory and other governmental agencies to again recognize the importance of weeds in agriculture, and have reinvigorated research and development efforts for new weed management strategies (Duke 2012). However, although the wide-spread existence of GR weeds has also resulted in the increased use of other herbicides, acceptance of nonherbicidal tactics has been limited at best (Owen et al. 2015). This lack of diversity for weed management has increased the selection pressures on weed populations for the evolution of resistance to these "alternate" herbicides, herein defined as herbicides other than glyphosate (WSSA Group 9). Importantly, two herbicide groups (WSSA Group 14 protoporphyrinogen oxidase inhibitors, and WSSA Group 27 4hydroxyphenyl-pyruvate-dioxygenase inhibitors) that are widely used to supplement WSSA Group 9 are now in serious jeopardy in U.S. crop systems due to evolved resistance in several important weed species, and it is increasingly common that these weeds have evolved multiple herbicide resistances (McMullan and Green 2011; Owen 2013; Owen et al. 2015; Patzoldt et al. 2005). Herbicide-based weed management is further complicated by the fact that no new herbicides with novel sites of action have been commercially introduced in almost three decades, and no new herbicide sites of action have been identified and developed (Duke 2012). It is clear that the suite of available weed management approaches has not been used as effectively as it could, given the extent of HR weed populations (Owen 1997).

\section{Best Management Practices for Herbicide- Resistant Weeds}

Best management practices (BMPs) for weed control have not changed substantively in several decades, although the emphasis on specific herbicides (i.e., glyphosate) has increased at the cost of alternate herbicides (i.e., all herbicides other than glyphosate) and more diverse practices (Gianessi 2013; Young 2006). A review of selected peerreviewed papers published over a seven-decade period reinforces the fact that the suite of BMPs has not changed appreciably (Table 1 ). What has changed in weed management are the specific tactics (e.g., herbicides, GE HR crop cultivars) and how they are being used. Weed scientists have done an excellent job of reporting science-based knowledge describing BMPs and presume that farmers will thus utilize this information appropriately, although some scientists recognize that many effective strategies have a poor chance of adoption by farmers (Green and Owen 2011; Swanton et al. 2008). Many surveys describe that farmers are using a number of BMPs specifically to help manage HR weeds (Arbuckle 2014; Arbuckle and Lasley 2013; Frisvold et al. 2009; Hurley et al. 2009c; Llewellyn et al. 2004). Frisvold et al. (2009) reported that $71 \%$ of corn (Zea mays L.), cotton (Gossypium hirsutum L.), and soybean [Glycine max (L.) Merr.] farmers used seven of the BMPs listed and that there was commonality among the crops with regard to the BMPs adopted. However, in these surveys, many highly effective practices (e.g., sanitation) are not adopted, yet others which are of lesser effectiveness or require little effort on the part of farmers (e.g., planting weed-free crop seed) are adopted frequently (Frisvold et al. 2009). Other tactics such as crop rotation are reported to be widely adopted and purportedly highly effective against HR weeds; however, as practiced (e.g., GR corn rotated with GR soybean), these BMPs contribute very little to mitigating the evolution of GR weeds (Arbuckle and Lasley 2013; Frisvold et al. 2009). The use of supplemental tillage and hand weeding, despite 
Table 1. Selected peer-reviewed papers describing tactics and diversity for weed management over seven decades.

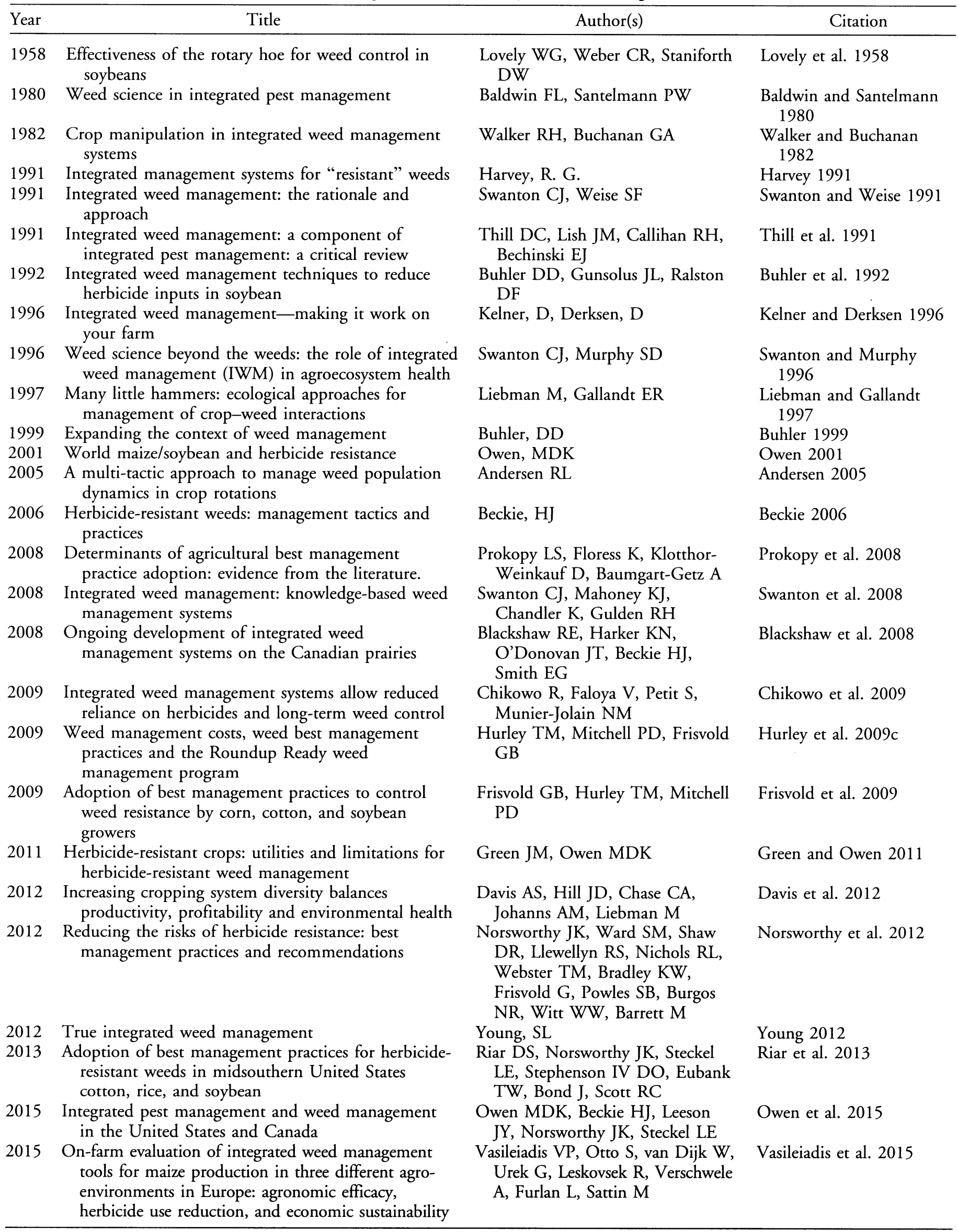


high levels of effectiveness in managing HR weeds, is avoided by a majority of farmers in row crop production systems (Arbuckle and Lasley 2013; Frisvold et al. 2009; Johnson and Gibson 2006). Farmers are also generally unwilling to consider using weed management programs that are developed for individual fields based on the specific characteristics of those fields, but would rather address the farm enterprise as one great field despite economic evidence supporting site-specific weed management (Switon 2005). The key to resolving these disconnects is to determine the specific components of the farm enterprise representing possible problems for farmers that result in decisions that do not support BMP use, and to identify what can be done to alleviate the hurdles and encourage greater diversity in the management of HR weeds and weeds in general.

\section{Adoption of Genetically Engineered Crops}

The unprecedented adoption of GE crops with glyphosate resistance moved weed management to a less diverse, more simplistic and highly convenient approach which has predictably resulted in the widespread evolution of GR weeds (Powles 2008). Despite the problem of GR weeds, there are many positive features of GE crops (Klümper and Qaim 2014). Benefits attributable to GE crop cultivars based on surveys, reports, and anecdotal information from some farmers, include reduced quantity and cost of pesticides and increased profitability (Frisvold and Reeves 2010; Klümper and Qaim 2014). Other agronomic factors that supported the adoption of GE crops were consistency of weed control, ability to use less tillage, and using safer herbicides (Cerdeira and Duke 2006; Ervin et al. 2010; Hurley et al. 2009c). Interestingly, in one survey, growers reported that factors such as family health, public health, and water quality were as important as many of the agronomic benefits attributed to GE crops (Hurley et al. 2009a,b). These same growers reported that soil erosion, wildlife quality, and time to apply were relatively unimportant considerations when assessing the adoption of GE crops. Curiously, the flexibility in weed management afforded by GE crop systems was evaluated to be of lower importance than crop safety, weed control consistency, and yield loss, but of higher importance than the time-to-apply factor (Hurley et al. 2009a,b).

\section{Barriers to Adopting Diverse Weed Management Tactics}

Despite that fact that many people involved with production agriculture recognize the risks of herbicide resistance in key weeds, little has been done to increase the acceptance of more holistic and diverse approaches for weed management that might resolve these issues. Holistic weed management implies programs that are inclusive and reflect many approaches to addressing weed management but not emphasizing any one strategy. Farmer awareness of and response to herbicide resistance varies, as does understanding the importance of diverse weed management, but most farmers associate weed management cost-effectiveness with herbicides and are hesitant to use integrated weed management (IWM) practices unless they are shown to have near-term economic value (Johnson and Gibson 2006; Llewellyn et al. 2004). Even then, farmers perceive greater risk and little benefit for preventative tactics addressing $\mathrm{HR}$ weeds (Doohan et al. 2010). Discussions that focus on proactive vs. reactive $\mathrm{HR}$ weed management suggest that more diverse strategies to delay the evolution of HR weeds are not economically attractive (Weersink et al. 2005). Farmers who focus on farming enterprise profitability are less likely to adopt diverse strategies and practice environmental stewardship (Reimer et al. 2012). This particularly could be the case for farmers who do not own the land, which includes a high percentage of the arable land under production in the United States (Owen et al. 2015). Furthermore, in U.S. row crops, the high levels of existing HR weed populations, particularly GR weed biotypes, make reactive strategies the only option in many instances (Owen et al. 2015).

Time-management issues are presumed to be a significant barrier to the adoption of greater diversity in weed management (Gunsolus 1990). Farm size continues to increase as farms and farm household numbers decline (Figure 1) (Anonymous 2015). There are fewer farmers managing more hectares over greater distances. For smaller farms, off-farm income is increasingly important, and labor availability is a problem that hampers the adoption of more diversity in weed management (Fernandez-Cornejo et al. 2005; Gardner et al. 2009). Tactics that enhance the diversity of weed management (e.g., scouting, mechanical control) not only must be timely relative to crop and weed stage of development but farmers also need time and labor to include these diverse practices.

Owen: Herbicide-resistant weed management • 


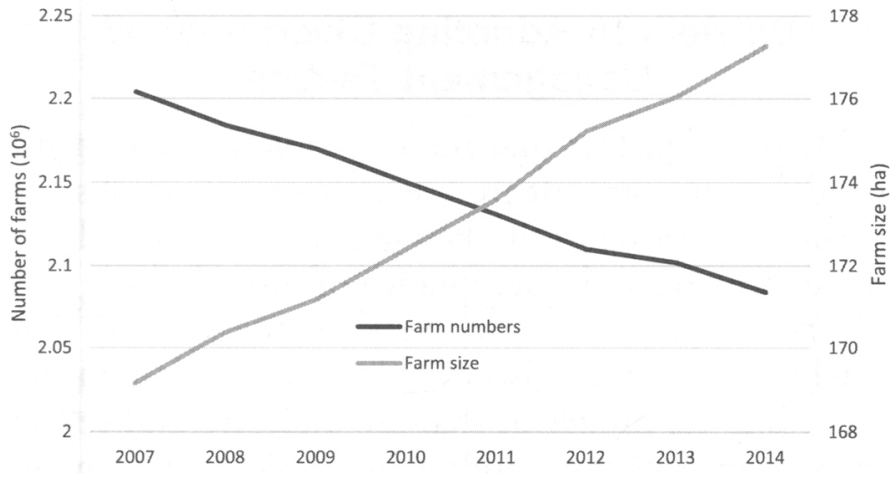

Figure 1. Number of farms and average farm size in the United States: 2007 to 2014 (Adapted from http://www.nass.usda.gov).

More diverse weed management tactics require the alignment of farm labor and time constraints with biological consideration, including days with conditions suitable for performing the management strategies that coincide with the appropriate stage of weed development (Gunsolus and Buhler 1999). With regard to diversity and the adoption of alternative practices, farmers gravitate to those that do not require major changes in the production system or do not require a major effort, such as planting weed-free crop seed. (Hurley et al. 2009c). Although there are benefits to more diverse systems, labor requirements can be a greater barrier to adoption despite profit opportunities similar to less diverse systems, less reliance on herbicides, and improved energy efficiencies (Table 2) (Davis et al. 2012; Liebman et al. 2008).

Interestingly in $2014,69 \%$ of Iowa farmers who were part of a survey about farmer perspectives on pesticide resistance suggested HR weeds were attributable to the poor management (i.e., lacking in diverse practices) of a few farmers (Arbuckle 2014). Farmers who participated in this survey reported that the responsibility for HR weeds was mostly attributable to farmers, followed closely by pesticide manufacturers and seed companies (Table 3; Arbuckle 2014). Pesticide applicators and university scientists were suggested to be similar in responsibility for HR weeds. Contrarily, in a similar survey conducted in Iowa in 2013 where there was a response rate of $56 \%$ (1,209 farmers), a majority of respondents indicated that they included diverse weed management tactics to address $\mathrm{HR}$ weeds (Figure 2; Arbuckle and Lasley 2013). These tactics included crop rotation, multiple herbicide applications, tillage, and multiple modes of herbicide action but did not include hand-weeding, interrow cultivation, cover crops, or the inclusion of a forage crop in the crop rotation. Clearly there is a disconnect in the perceptions reported by farmers who participated in the surveys and the reality, given that herbicide resistance in Iowa continues to increase (Owen et al. 2015).

The economic cost of more diverse strategies represents a major barrier to the adoption of more holistic weed management when compared with the recent historic simple and convenient tactic of glyphosate-based weed management (Hurley et al. 2009c; Weersink et al. 2005). Not surprisingly, farmers that adopt some diverse tactics (BMPs) for control of HR weeds fail to adopt three that are effective, in part because these practices are likely the most costly (Frisvold et al. 2009). These BMPs are sanitation, use of multiple herbicides with different modes of action, and supplemental tillage (e.g., interrow cultivation); the lack of adoption is consistent across cotton, corn, and soybean. Holistic approaches that focus on herbicides and tillage can also be more environmentally costly, given the increased usage of herbicides, the physicochemical characteristics of alternate herbicides, and the potential impact of tillage on soil erosion and water quality (Cerdeira and Duke 2006; Frisvold et al. 2009). Reports suggest that farmers might not understand the implications of herbicide modes of action (MOAs) on the evolution of herbicide resistance in weeds and might not realize the importance of herbicide rate, tank mixtures, and the need to use herbicides that are effective on the target weeds rather than to just increase the number

Table 2. Revenues, costs, and labor requirements for three crop rotations. Adapted from Liebman et al. (2008).

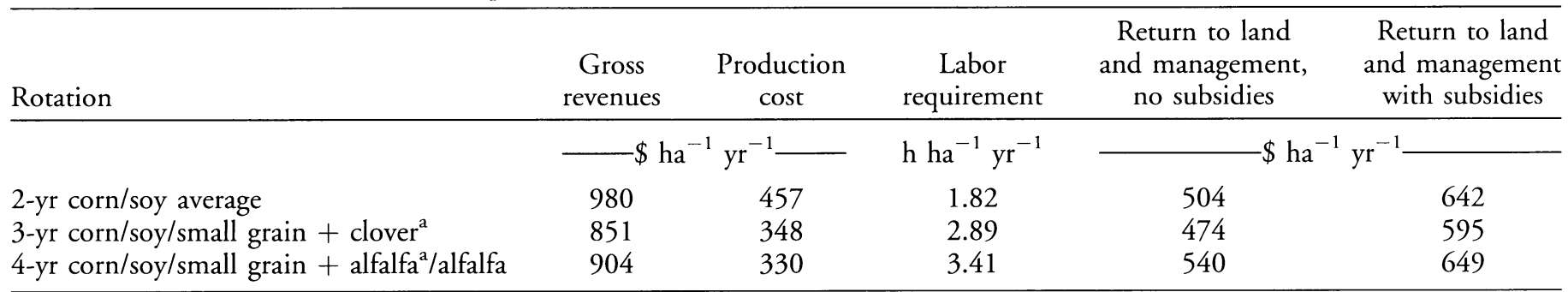

${ }^{a}$ The small grain and clover or alfalfa were interseeded. 
Table 3. Assessment of responsibility for herbicide-resistant weed management. Adapted from Arbuckle (2014).

\begin{tabular}{|c|c|c|c|c|}
\hline & No responsibility & Little responsibility & Some responsibility & Much responsibility \\
\hline Farmers & 1.2 & 4.6 & 32.4 & 61.8 \\
\hline Seed companies & 2.7 & 8.3 & 44.4 & 44.7 \\
\hline University scientists & 5.7 & 15.6 & 42.5 & 36.2 \\
\hline Pesticide applicators (commercial) & 5.4 & 16.9 & 44.7 & 33.0 \\
\hline
\end{tabular}

of herbicides used (Beckie 2006; Beckie and Reboud 2009; Johnson and Gibson 2006).

There is a tendency for farmers to delay actions to address HR weeds until the problem "exists," which is to say it is recognized by the individual farmer (Frisvold and Reeves 2010; LLewellyn et al. 2004). The failure to recognize the existence of $\mathrm{HR}$ weeds in fields might be attributable, in part, to the fact that growers do not scout fields after herbicide applications. Given the perception of increased economic costs for proactive HR weed management, procrastination by farmers until all other possibilities (e.g., weather) that might explain poor weed control are ruled out is not surprising. However the problem with this approach is the fact that several reproductive cycles have occurred, equipment has effectively dispersed the HR biotype throughout the field(s), and the HR biotype now represents a formidable component of the overall weed population such that the ability of farmers to effectively manage the problem have been severely compromised and the cost of addressing the problem has escalated.

Perhaps the greatest barrier to addressing the evolution of HR weeds is that fact that many farmers believe that the problem is outside of their control (Doohan et al. 2010; Wilson et al. 2008).

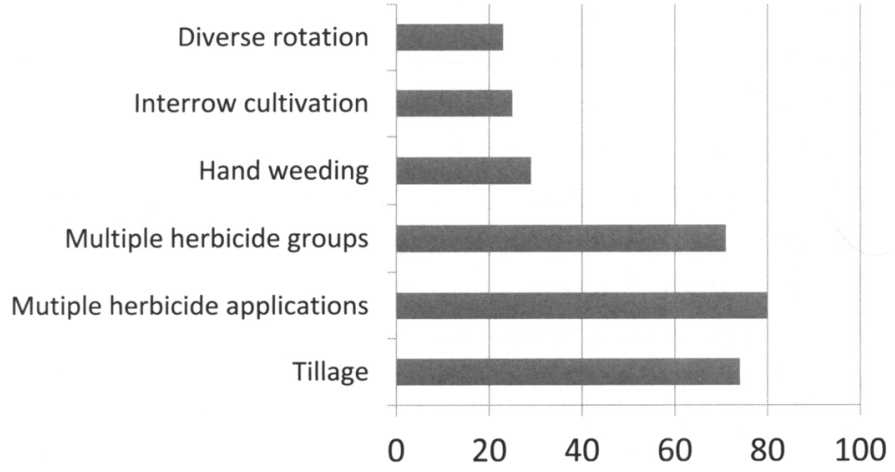

Figure 2. Percent of Iowa farmers using diverse tactics to manage herbicide-resistant weeds (Adapted from Arbuckle and Lasley 2013).
Environmental factors, weed characteristics, and the actions of neighbors are thought to be of greater importance with regard to the movement and introduction of weeds. and thus compromise any preventative actions that a farmer might undertake. Although farmers might hear the message about the need for diverse and integrated approaches to prevent problems with HR weeds, they fail to implement these practices because of the fear that new weeds will inevitably be introduced and will spread across the landscape regardless of what the individual farmer might do (Wilson et al. 2008).

This feeling of helplessness and the inevitability that weeds will continue to be a problem regardless of what a farmer might do emphasizes the complexity of the barriers minimizing the adoption of diverse weed management tactics, and enforces the need for new approaches that bring into play the local or perhaps even the extended "community" to address HR weeds (Doohan et al. 2010). There is a need for community-based initiatives incorporating important principles to reconcile agronomic and ecological concerns in order to more effectively manage HR weeds across the landscape (Frisvold and Reeves 2010; Sayer et al. 2013). These principles include-but are not limited to-facilitating collective farmer action to manage $\mathrm{HR}$ weeds across an extended area, providing information to government agencies about regulatory effectiveness, making sure that multiple stakeholders are engaged in HR weed management, and establishing a negotiated and transparent logic for $\mathrm{HR}$ weed management, including participatory monitoring of HR weed management and clarification of stakeholder rights and responsibilities. Communitybased approaches to agronomic problems have been effective for a number of crop systems and pests; there are socioeconomic barriers as well as agronomic factors that need to be identified to better address the opportunities for more diverse management strategies to address HR weeds (Ervin and Jussaume 2014). To that end, the Cooperative

Owen: Herbicide-resistant weed management • 575 
Extension Service (CES) can and should facilitate community-based efforts to establish "area-wide" HR weed management. These efforts must include a diverse suite of practices beyond herbicides, selected by the community. Furthermore the CES should interact with government agencies (e.g., Environmental Protection Agency, National Resource Conservation Service), and private industry (e.g., agricultural chemical and seed companies) in support of community-based HR weed management initiatives so that farmers are provided with consistent regulatory authority to best address the burgeoning problem of HR weeds (Frisvold and Reeves 2010). Any government programs should consider farmer stewardship ethics and their concern for the environment as well as addressing profitability (Greiner and Gregg 2011). Although individual farmers might address $\mathrm{HR}$ weed management differently than their neighbors, sitespecific programs can be effective and profitable if imposed at the landscape scale (Switon 2005). However, overcoming the barriers already described remains an imposing issue for $\mathrm{HR}$ weed management as well as community-based efforts.

\section{Herbicide-Use Practices and Herbicide Resistance in Weeds}

Herbicides will continue to play an important role in weed management for most crop systems, despite the increasing problem of evolved resistance to herbicides, and social and political pressures to reduce pesticide use (Brookes 2014; Buhler et al. 2000; Vasileiadis et al. 2013). How herbicides are used is clearly an important factor affecting selection pressures imposed on weed populations that inevitably result in the evolution of $\mathrm{HR}$ weed biotypes (Baker 1974; Gould 1991; Gressel 1991, 2009). It is (or should be) obvious that resistance to atrazine (WSSA Group 5) was due to the widespread global use of this herbicide (LeBaron 2008). Similarly, resistance to ALS-inhibiting herbicides (WSSA Group 2) was attributable to grower use practices as well as marketing programs in the 1980s and 1990s (Shaner 2014; Tranel and Wright 2002). Despite scientific evidence that the recurrent use of specific herbicides would result in evolved resistance in weeds, many farmers, custom applicators, and companies who sell herbicides did not accept this ecological truism and refused to change weed management strategies. Arguably the most important and impactful misuse of herbicides was with GR crops and glyphosate. Glyphosate quickly changed from a herbicide that was used almost exclusively to control weeds prior to planting in no tillage production systems and typically used in combination with other herbicides (e.g., 2,4-D) to the principal, and often the only herbicide used for weed control in corn, cotton, and soybean; this misuse predictably facilitated the evolution of GR weeds (Duke and Powles 2008; Powles 2008; Shaner 2014; VanGessel 2001; Young 2006).

The use of reduced herbicide rates has been another important factor in the evolution of herbicide resistance in weeds. Many farmers, in an effort to reduce production costs, inadvisably opted to use less-than-labeled rates of highly effective herbicides, which increased the selection for polygenic evolved herbicide resistances (Gressel 2011). Agricultural chemical companies also recommend lower dosages of herbicides in prepackaged mixtures and continue to market these combinations as effective tools to manage HR weeds. However, rigid ryegrass (Lolium rigidum Gaudin) rapidly evolved resistance when exposed to reduced diclofop (WSSA Group 1) rates (Manalil et al. 2011, 2012). The occurrence of glyphosate resistance was enhanced when low dosages were used in rigid ryegrass populations and the response of these populations to paraquat was also reduced (Busi et al. 2012; Busi and Powles 2009, 2011). It is suggested that low herbicide dosages select for polygenic resistance, particularly nontarget site resistance (Busi et al. 2011, 2013). Low herbicide dosages can result in high numbers of weeds surviving the treatment. These survivors might have genes that provide a modicum of herbicide resistance which can then accumulate in subsequent generations in cross-pollinated weed species, and in particular in species that are obligate out-crossers (Gressel 2011; Manalil et al. 2011).

The number of herbicides that are used and how they are combined also impacts the evolution of $\mathrm{HR}$ weeds. The recommendation to use multiple MOAs is a tactic that is prevalent in herbicide marketing and has gained some acceptance with farmers. It is also included as a recommendation endorsed by the Weed Science Society of America (Norsworthy et al. 2012). However, different MOAs were not widely used by corn, cotton, or soybean farmers when compared with other weed management practices, and grower lack of understanding about herbicide MOAs likely contributes to the relatively low adoption (Frisvold et al. 2009; Johnson and Gibson 2006). 
Rotation of herbicide MOAs is also recommended in addition to using herbicides in combinations. Unfortunately, a critically important detail that is often overlooked or ignored is the effectiveness of the herbicide MOA on the target weed; for example, rotating or combining a WSSA Group 2 product is unlikely to contribute to $\mathrm{HR}$ weed management, given the widespread resistance to WSSA Group 2 herbicides in weeds such as tall waterhemp [Amaranthus tuberculatus (Moq.) Sauer [syn. A. rudis Sauer]) and Palmer amaranth (Amaranthus palmeri S. Wats.) (Heap 2015). Rotating herbicide MOAs increased the occurrence of GR tall waterhemp when compared with herbicide MOA mixtures applied in combination (Evans et al. 2015). The level of WSSA Group 2 resistance in the weed seed bank after 4 yr of effective herbicide MOA combinations was the same as the levels in the weedy control or where WSSA Group 2 herbicides were not applied, and clearly supports the view that mixtures of effective herbicide MOAs are better than herbicide MOA rotations in mitigating herbicide resistance evolution attributable to herbicide selection (Beckie and Reboud 2009). However, full labeled herbicide dosages must also be used when effective herbicide MOAs are applied in combinations. Often herbicide rates are reduced when combinations of products are applied in an effort to reduce costs.

\section{Mechanical Tactics that Contribute to a Diverse Approach to Herbicide-Resistant Weed Management}

Tillage is the most important selective factor in agriculture given the implications of the resulting disturbance on the weed community, particularly with regard to the weed seedbank (Owen 2008). Furthermore, tillage is a fundamental tactic for weed control and has been practiced since the beginning of agriculture. However, tillage has environmental, economic, and time utilization costs that have made mechanical weed control less acceptable to farmers, particularly given the success of glyphosate-based production systems (Cerdeira and Duke 2006). There are also governmental regulatory implications affecting the availability of tillage to farmers in some crop production areas. Given the increasing problems with GR weeds and herbicide resistance in general, tillage should be considered as a component of a diverse IWM program but tailored to minimize concerns about costs incurred. Tillage can be divided into two general types: primary tillage done prior to the establishment of the crop, and secondary tillage for weed management during the development of the crop.

Primary tillage contributes most to the environmental costs and has changed the most with the adoption of GR crops. No-till production, particularly in corn, cotton, and soybean, is supported by the availability of glyphosate used in-crop and provides the greatest environmental and economic savings for growers. There are tillage practices that can be used that still maintain significant plant residues on the soil surface and support effective weed management (Bates et al. 2012); however, these conservation tillage practices increase the complexity of crop management decisions and add costs and time to crop production, hindering their adoption by farmers. Rotational tillage (e.g., using tillage $1 \mathrm{yr}$ out of 4) can mitigate most of the environmental risks such as soil erosion while providing the weed management benefits needed to address HR weeds. However, there is a perception in agriculture by many farmers that weeds on all acres of a farm enterprise must be managed similarly. This perception is contrary to the basic principles of IWM as well as established agronomic practices already in place, such as selection of crop cultivars and fertilizer use, and must be addressed in order to provide more options for farmers to better manage HR weeds. Secondary tillage practices (e.g., interrow cultivation, rotary hoe) provide considerable benefit and opportunity for holistic HR weed management. However, the timeliness requirement for effective secondary mechanical weed control is a major constraint for many farmers, given the trend of increasing size of farming enterprise (Figure 1). Although mechanical weed control practices can be highly effective if conducted in a timely fashion with regard to weed and crop development, time constraints can limit adoption (Gunsolus 1990; Lovely et al. 1958).

Interrow cultivation has facilitated reduced use of herbicides without compromising crop yield. In 64 on-farm comparisons over $5 \mathrm{yr}$, band herbicide application with interrow cultivation had similar corn yields when compared with broadcast herbicides in all but four locations (Hartzler et al. 1993).

Again, the desire to keep things convenient and simple must be addressed: secondary tillage for HR weed control needs to be implemented only where required in specific fields, or even specific portions of individual fields, rather than applied to the entire farm enterprise. Innovative secondary tillage prac-

Owen: Herbicide-resistant weed management 577 
tices such as using a paraplow and mechanical "diggers" also have promise in managing particularly difficult weeds (Hershenhorn et al. 2015).

\section{Cultural Tactics that Contribute to a Diverse Approach to Herbicide-Resistant Weed Management}

Cultural tactics to help manage $H R$ weeds include more diverse crop rotations, adjustment of planting time, seed rates, cover crops, planting configurations, and others. Importantly, cultural strategies are best used in combination with other weed management tactics because alone they might provide only a modicum of effective $H R$ weed control (Liebman and Gallandt 1997). Cereal rye cover crops (Secale cereale L.) not only reduced Palmer amaranth biomass in cotton but also impacted the critical period for weed control (Korres and Norsworthy 2015). Cereal rye used prior to soybean in a corn/soybean rotation provided similar suppression of weeds compared to a two-pass herbicide treatment when weed population density was low, but supplemental herbicides were required when weed population density was high (De Bruin et al. 2005). Cover crops in combination with tillage are more effective at controlling $\mathrm{HR}$ weeds than either tactic alone (DeVore et al. 2012, 2013; Sosnoskie and Culpepper 2013).

Although the literature is replete with references that suggest narrowing crop row spacing and increasing crop plant populations reduces weed competition and increases yield (Harker et al. 2012; Mortensen et al. 2012; Vencill et al. 2012), there are also examples suggesting that this might not be a consistent effect and that there are many interacting factors (De Bruin and Pedersen 2009; DeWerff et al. 2014; Rich and Renner 2007). For example, there was no difference in the critical period for weed control or crop competitiveness on late-season weeds comparing wide- and narrow-row corn (Norsworthy and Oliveira 2004). Increasing crop plant populations may negate the economic return on greater potential yield and improved competition on HR weeds, given the high cost of crop seed, although De Bruin and Pedersen (2008) reported that soybean seed rates can be reduced in narrow rows such that the yield potential attributable to narrow rows and economic benefits from using lower seeding rates are balanced. Scale of the farm enterprise must be considered when altering crop population density and row width, as well as crop cultivar and fertility (De Bruin and Pedersen 2008).

\section{Seed Bank Management and Sanitation that Contribute to a Diverse Approach to Herbicide-Resistant Weed Management}

One of the most important considerations for integrated pest management (IPM) is the adoption of pest thresholds such that pests are only controlled when the population numbers increase to the point that economic damage to the crop results (economic injury level [EIL]) (Bottrell 1979). However, this IPM concept was developed to address issues with arthropods and does not reflect the biology or economics of weeds and importantly, HR weeds. The use of EIL has no ecological basis in managing HR weeds, given the fecundity of weeds and the implications of seed dormancy with regard to future HR weed populations (Norris 1999). Given that much arable land is not farmed by the owner, weeds that would be left in the field if thresholds were adopted would jeopardize lease agreements (Owen et al. 2015). There are also concerns about whether or not data generated to describe weed seed production and used in predictive models are accurate given the regional variation in environmental conditions and differences in procedures used to generate the data (Norris 2007). Weeds have plasticity of growth, so damage from individual weeds growing under lower population densities can be greater than damage caused by weeds developing under higher population densities; these weeds will also produce seeds that potentially increase the future weed population density (Pichancourt and van Klinken 2012). Despite efforts to implement weed thresholds in crop production, the adoption of this IPM tactic has not been realized in commercial agriculture.

Regardless, it is clear that effective and diverse HR weed management must address the weed seedbank. A strong case has been made for zero thresholds of HR weeds, thus eliminating the replenishment of the seed bank (Norsworthy et al. 2014). However, attempting to achieve zero thresholds for HR weeds begs the question of whether or not this is a realistic and economically appropriate goal in most crop systems. A number of strategies and equipment concepts have been publicized in Australia that address postharvest management of the weed seedbank (Walsh et al. 2012). However, these tactics were developed in a specific crop production system focusing on small 
grains, and there are concerns about the adoption of these practices in U.S. agriculture, particularly when considering the high level of stover in Midwest corn production. The idea of harvest-time weed seed management is not a new or novel concept (Dion 1948). There are questions about whether the target weeds will retain seeds until harvest, although anecdotal information suggests that with Palmer amaranth at least, a high percentage of seeds remain with the mother plant until harvest (JK Norsworthy, personal communication). It is important to recognize that weed seedbank management is one tactic, but it will not be successful in reducing HR weed populations if used alone (Walsh et al. 2012). Successful reductions in the weed seedbank occur when seed destruction is accompanied by diverse tactics, including successful herbicide programs. This is a concern given the multiple resistances that exist in many weeds targeted for seedbank management practices, because there might not be effective herbicide options, thus compromising the effectiveness of this approach (Gressel and Levy 2014). There are also questions about the energy cost of seed destruct equipment relative to the benefits, and the impact that current equipment might have on harvesters. Anecdotal information from farm equipment companies suggest that current harvesters could be modified to effectively address weed seedbank management, depending on the value to growers and the costs of modification. Other tactics that focus on weed seedbank management developed in Australia, such as winnowing crop and weed residues and burning them to destroy weed seed viability, and collecting crop and weed residues in a "chaff cart" and removing these from fields, are not likely viable in much of the United States, given the environmental concerns that the fires would cause and the high level of crop residues that are found in Midwest corn fields.

\section{Robotics, Drones, and Other Technologies and Ideas That Could Contribute to a Diverse Approach for Herbicide-Resistant Weed Management}

Given the changes that have occurred in production agriculture attributable, in part, to the unprecedented adoption of GE crops and the unintended consequences (i.e., widespread evolution of herbicide resistance), factors such as improved time utilization efficiency, environmentally supportive strategies, greater diversity of practices, and cost of holistic weed management are key to the success of HR weed management in the future (Young and Pierce 2014). Robotics for pest management, particularly for weed complexes, might be the best future option (Prince et al. 2012). Theoretically, robotics as a component of a holistic HR weed management program could include mechanical, cultural, and herbicidal tactics with an emphasis on site-specific management, possibly to the scale of individual weeds in the field. A robotics approach could dramatically improve the timeliness of each tactic, as well as labor and time utilization efficiency, compared to current practices. However, there are a number of technological problems that must be overcome before robotic $H R$ weed management becomes a reality.

The use of drones for HR weed management represents an important opportunity to increase field scouting in a timely and efficient manner that is unavailable for current production agriculture.

Time utilization efficiency should be greatly improved, increasing the adoption of field scouting, which is critically important for all approaches for IWM. However, there are again technological issues with regard to the ability of drones to distinguish weeds from crops at an elevation that makes their use reasonable for larger fields. Efforts with regard to spectral recognition have shown promise, but this technology is not yet available. Furthermore, there are a number of legal and regulatory issues surrounding drone use that must be addressed. Finally, there are as yet no data that support the cost and effectiveness of using drones for field scouting weeds. Is the precision and accuracy of using drones for field scouting sufficient to provide the information necessary to make key HR weed management decisions?

Other interesting options for diverse management of HR weeds exist or are under development. Technologies that "sense" and potentially identify by genus and species weeds in corn interrows could improve the efficiency of POST management strategies if successful (Longchamps et al. 2012). There a number of ground-based sensors that could allow weeds to be detected and levels of infestation assessed (Peteinatos et al. 2014). A technology to sense weeds, if able to accomplish this in a timely manner, would greatly improve the success of postemergence-applied herbicides, assess localized "hot spots" that might require mechanical control tactics, and would support future robotic weed management when and if developed. Flame weeding is another alternate technology that has a use in some crop systems, particularly organic and vege-

Owen: Herbicide-resistant weed management • 579 
table crop production where herbicides are either not used or not labeled (Ulloa et al. 2010). Radioor microwave energy might prove successful in controlling existing weeds and reducing the weed seedbank (Brodt et al. 2004). This technology would also prove useful in organic and vegetable crop production, as previously suggested. Finally, the use of animals (e.g., geese and goats) to selectively control weeds in specific crop and noncrop systems has seen some success (Wurtz 1995). Although not likely useful in row crops, given the scale of crop production, this tactic might be useful in controlling HR weeds in field margins and rights-of-way.

\section{Last Thoughts}

Herbicide-resistant weeds have occurred for almost five decades. However, the dominance of the broad-spectrum herbicide, glyphosate, when used in conjunction with glyphosate-resistant crop cultivars was unprecedented; thus, when glyphosate resistance appeared and propagated, concerns about herbicide resistance escalated. Given the unprecedented adoption of GR crops, the almost exclusive use of glyphosate to control weeds and the rhetoric that supported these practices, many growers were unprepared to manage GR weeds. Moreover, the widespread use of glyphosate overrode the substantial field presence of resistance to other herbicide mechanisms of action, such as the HR 2 herbicides. Thus, when glyphosate failed against critical weed species, developing an effective economic response was and remains challenging. Although the technological aspects of weed management have dominated our discipline, and historically, efficient and costeffective methods to control weeds have been developed, social and economic changes in agriculture occurring in part as a result of crop production systems based on glyphosate have made the job of establishing new and effective strategies more challenging.

Herbicides will continue to be critical components of future weed management, but it is clear that focusing solely on herbicide solutions to HR weeds will not resolve the problem across the landscape. Importantly, if new mechanisms of herbicide action are not forthcoming in the near future, it is also clear that herbicides will need to be supplemented by other means. Furthermore, although there is a sound knowledge base supporting IWM, the barriers to adopting a more diverse approach to managing $\mathrm{HR}$ weeds are formidable and might not be fully understood.

The prevailing question is clearly what must be done to management HR weeds, and more broadly, weeds in general. How can agriculture steward the currently available herbicides in order to preserve their efficacy? How can weed management programs with sufficient diversity be adopted across the landscape so that selection for a suite of weeds with evolved resistance to one or more herbicides can be avoided? Can these diverse weed management programs meet the agricultural, sociological, and economic barriers that either exist or are perceived to exist in current crop production systems?

The fact that many farmers believe that they are doing all that they can to manage HR weeds and that agricultural chemical companies continue to promote products that might not be effective for current HR weed management is concerning. Also telling is that farmers might not feel that their individual efforts are sufficient to address herbicide resistance. Current problems with HR weeds might be not as much with the lack of technology, but rather socioeconomic issues that cannot be successfully addressed using past approaches. Farmers must address HR weeds at the landscape level if they are to have any likelihood of sustainably managing the problem successfully, which will require that farmers band together and approach HR weed management as a community. Is this a reasonable and feasible expectation?

It should also be evident that addressing HR weeds with herbicides will be less than successful given the lack of new effective herbicides. Unless diverse approaches to HR weed management are widely adopted, it is inevitable that evolved herbicide resistances in key weeds will continue to increase and costs to agriculture and consumers will continue to escalate. Given the socioeconomic factors that drive agronomic decisions and the changing demographics in agriculture, it is critically important that all opportunities and components of holistic HR weed management be studied, assessed, and publicized. This will require not only research and outreach in new technologies, but also understanding the reasons why farmers decide on some tactics but are reticent to adopt other practices that could increase the diversity of a crop system and thus improve the management of HR weeds. Weed scientists must expand their horizons to address the social and economic problems associated with the current demographics of agriculture, just as 
farmers must diversify their approaches to weed management, and these efforts must be broadly supported by the agricultural community including-but not limited to-applicators, herbicide manufacturers, and governmental agencies.

\section{Literature Cited}

Anderson RL (2005) A multi-tactic approach to manage weed population dynamics in crop rotations. Agron J 97:1679-1583

Anonymous (2015) Farms and Land in Farms 2014 Summary. U.S. Department of Agriculture National Agricultural Statistics Service. Washington DC: U.S. Department of Agriculture. $20 \mathrm{p}$

Arbuckle JR (2014) Farmer Perspectives on Pesticide Resistance. Report RM 3070. Ames, IA: Iowa State University. 8 p

Arbuckle JR, Lasley, P (2013) Iowa Farm and Rural Life Poll: 2013 Summary Report. Report PM 3061. Ames, IA: Iowa State University. $20 \mathrm{p}$

Baker HG (1974) The evolution of weeds. Annu Rev Ecol Syst 5:1-24

Baker HG (1991) The continuing evolution of weeds. Econ Bot 45:445-449

Baldwin FL, Santelmann PW (1980) Weed science in integrated pest management. BioScience 30:675-678

Bates RT, Gallagher RS, Curran WS, Harper JK (2012) Integrating mechanical and reduced chemical weed control in conservation tillage corn. Agron J 104:507-512

Beckie HJ (2006) Herbicide-resistant weeds: management tactics and practices. Weed Technol 20:793-814

Beckie HJ, Reboud X (2009) Selecting for weed resistance: herbicide rotation and mixture. Weed Technol 23:363-370

Blackshaw RE, Harker KN, O'Donovan JT, Beckie HJ, Smith EG (2008) Ongoing development of integrated weed management systems on the Canadian prairies. Weed Sci 56:146-150

Bottrell DG (1979) Integrated Pest Management. Berkeley, CA: Consortium for International Crop Protection. $121 \mathrm{p}$

Brodt S, Klonsky K, Tourte L, Duncan R, Hendricks L, Ohmart C, Verdegall P (2004) Influence of farm management style on adoption of biologically integrated farming practices in California. Renew Agr Food Syst 19:237-247

Brookes G (2014) Weed control changes and genetically modified herbicide tolerant crops in the USA 1996-2012. GM Crops Food: Biotechnol Agric Food Chain 5:321-332

Buhler DD (1999) Expanding the context of weed management. New York: Haworth Press. $289 \mathrm{p}$

Buhler DD, Gunsolus JL, Ralston DF (1992) Integrated weed management techniques to reduce herbicide inputs in soybean. Agron J 84:973-978

Buhler DD, Liebman M, Obrycki JJ (2000) Theoretical and practical challenges to an IPM approach to weed management. Weed Sci 48: 274-280

Busi R, Gaines TA, Walsh MJ, Powles SB (2012) Understanding the potential for resistance evolution to the new herbicide pyroxasulfone: field selection at high doses versus recurrent selection at low doses. Weed Res 52:489-499

Busi R, Neve P, Powles S (2013) Evolved polygenic herbicide resistance in Lolium rigidum by low-dose herbicide selection within standing genetic variation. Evol Appl 6:231-242
Busi R, Powles SB (2009) Evolution of glyphosate resistance in a Lolium rigidum population by glyphosate selection at sublethal doses. Heredity 103:318-325

Busi R, Powles SB (2011) Reduced sensitivity to paraquat evolves under selection with low glyphosate doses in Lolium rigidum. Agron Sust Devel 31:525-531

Busi R, Vila-Aiub MM, Powles SB (2011) Genetic control of a cytochrome P450 metabolism-based herbicide resistance in Lolium rigidum. Heredity 106:817-824

Cerdeira AL, Duke SO (2006) The current status and environmental impacts of glyphosate-resistant crops: a review. J Environ Qual 35:1633-1658

Chikowo R, Faloya V, Petit S, Munier-Jolain NM (2009) Integrated weed management systems allow reduced reliance on herbicides and long-term weed control. Agr Ecosyst Environ 132:237-242

Davis AS, Hall JC, Jasieniuk M, Locke MA, Lushei EC, Mortensen DA, Riechers DE, Smith RG, Sterling TM, Westwood JH (2009) Weed science research and funding: a call to action. Weed Sci 57:442-448

Davis AS, Hill JD, Chase CA, Johanns AM, Liebman M (2012) Increasing cropping system diversity balances productivity, profitability and environmental health. Plos One 7:e47149

De Bruin JL, Pedersen P (2008) Effect of row spacing and seeding rate on soybean yield. Agron J 100:704-710

De Bruin JL, Pedersen P (2009) Growth, yield, and yield component changes among old and new soybean cultivars. Agron J 101:124-130

De Bruin JL, Porter PM, Jordan NR (2005) Use of a rye cover crop following corn in rotation with soybean in the upper midwest. Agron J 97:587-598

Delye C, Jasieniuk M, Le Corre V (2013) Deciphering the evolution of herbicide resistance in weeds. Trends Genet 29:649-658

DeVore JD, Norsworthy JK, Brye KR (2012) Influence of deep tillage and a rye cover crop on glyphosate-resistant Palmer amaranth (Amaranthus palmeri) emergence in cotton. Weed Technol 26:832-838

DeVore JD, Norsworthy JK, Brye KR (2013) Influence of deep tillage, a rye cover crop, and various soybean production systems on Palmer amaranth emergence in soybean. Weed Technol 27:263-270

DeWerff RP, Conley SP, Colquhoun JB, Davis VM (2014) Can soybean seeding rate be used as an integrated component of herbicide resistance management? Weed Sci 62:625-636

Dion FA, inventor; Fred AzDiOll, assignee (1948) 2 April 1948. Auxiliary grain separator for combines. U.S. patent 2617425. 1948 April 2

Doohan D, Wilson R, Canales E, Parker J (2010) Investigating the human dimension of weed management: new tools of the trade. Weed Sci 58:503-510

Duke SO (2012) Why have no new herbicide modes of action appeared in recent years? Pest Manag Sci 68:505-512

Duke SO, Powles SB (2008) Glyphosate: a once-in-a-century herbicide. Pest Manag Sci 64:319-325

Duke SO, Powles SB (2009) Glyphosate-resistant crops and weeds: now and in the future. AgBioForum 12:346-357

Ervin D, Jussaume R (2014) Integrating social science into managing herbicide-resistant weeds and associated environmental impacts. Weed Sci 62:1-12

Ervin DE, Carriere Y, Cox WJ, Fernandez-Cornejo J, Jussaume RA Jr, Marra MC, Owen MDK, Raven PH, Wolfenbarger LL, Zilberman D (2010) The Impact of Genetically Engineered

Owen: Herbicide-resistant weed management • 581 
Crops on 'Farm Sustainability in the United States. Washington, DC: National Research Council. $250 \mathrm{p}$

Evans JA, Tranel PJ, Hager AG, Schutte B, Wu C, Chatham LA, Davis AS (2015) Managing the evolution of herbicide resistance. Pest Manag Sci 72:74-80

Fernandez-Cornejo J, Hendricks C, Mishra A (2005) Technology adoption and off-farm household income: the case of herbicide-tolerant soybeans. J Agr Appl Econ 37:549-563

Frisvold GB, Hurley TM, Mitchell PD (2009) Adoption of best management practices to control weed resistance by corn, cotton, and soybean growers. AgBioForum 12:370-381

Frisvold, GB, Reeves JM (2010) Resistance management and sustainable use of agricultural biotechnology. AgBioForum 13:343-359

Gardner JG, Nehring RF, Nelson CH (2009) Genetically modified crops and household labor savings in US crop production. AgBioForum 12:303-312

Gianessi LP (2013) The increasing importance of herbicides in worldwide crop production. Pest Manag Sci 69:1099-1105

Gould F (1991) The evolutionary potential of crop pests. Am Sci 79:496-507

Green JM, Owen MDK (2011) Herbicide-resistant crops: utilities and limitations for herbicide-resistant weed management. J Agr Food Chem 59:5819-5829

Greiner R, Gregg D (2011) Farmers' intrinsic motivations, barriers to the adoption of conservation practices and effectiveness of policy instruments: empirical evidence from northern Australia. Land Use Policy 28:257-265

Gressel J (1991) Why get resistance? It can be prevented or delayed. Pages 1-26 in Caseley JC, Cussons GW, Atkin RK, eds. Herbicide Resistance in Weeds and Crops. Oxford: Butterworth-Heinemann

Gressel J (2009) Evolving understanding of the evolution of herbicide resistance. Pest Manag Sci 65:1164-1173

Gressel J (2011) Low pesticide rates may hasten the evolution of resistance by increasing mutation frequencies. Pest Manag Sci 67:253-257

Gressel J, Levy AA (2014) Use of multicopy transposons bearing unfitness genes in weed control: four example scenarios. Plant Physiol 166:1221-1231

Gunsolus JL (1990) Mechanical and cultural weed control in corn and soybean. Am J Altern Agric 5:114-119

Gunsolus JL, Buhler DD (1999) A risk management perspective on integrated weed management. Pages 167-187 in Buhler DD, ed. Expanding the Context of Weed Management. Binghampton, NY: Food Products Press

Hails RS (2005) Assessing the impact of genetically modified crops on agricultural biodiversity. Minerva Biotecnol 17:1320

Harker KN, O’Donovan JT, Blackshaw RE, Beckie HJ, MallorySmith C, Maxwell BD (2012) Our view. Weed Sci 60:143144

Harper JL (1956) The evolution of weeds in relation to resistance to herbicides. Pages 179-188 in Kasasian L, ed. Proceedings of the 3rd British Weed Control Conference. Farnham, United Kingdom: British Weed Control Council

Hartzler RG, Van Kooten BD, Stoltenberg DE, Hall EM, Fawcett RS (1993) On-farm evaluation of mechanical and chemical weed management practices in corn (Zea mays). Weed Technol 7:1001-1004

Harvey RG (1991) Integrated management systems for "resistant" weeds. Pages 89-90 in Proceedings of the North Central
Weed Science Society. Indianapolis, IN: North Central Weed Science Society [Abstract]

Heap I (2015) The International Survey of Herbicide Resistant Weeds. www.weedscience.com. Accessed July 13, 2015

Hershenhorn J, Zion B, Smirnov E, Weissblum A, Shamir N, Dor E, Achdari G, Ziadna H, Shilo A (2015) Cyperus rotundus control using a mechanical digger and solar radiation Weed Res 55:42-50

Hurley TM, Mitchell PD, Frisvold GB (2009a) Characteristics of herbicides and weed-management programs most important to corn, cotton, and soybean growers. AgBioForum 12:269280

Hurley TM, Mitchell PD, Frisvold GB (2009b) Effects of weedresistance concerns and resistance-management practices on the value of Roundup Ready crops. AgBioForum 12:291-302

Hurley TM, Mitchell PD, Frisvold GB (2009c) Weed management costs, weed best management practices and the Roundup Ready weed management program. AgBioForum 12:281-290

Johnson WG, Gibson KD (2006) Glyphosate-resistant weeds and resistance management strategies: an Indiana grower perspective. Weed Technol 20:768-772

Kelner D, Derksen D (1996) Integrated weed managementmaking it work on your farm. http://www.agriculture.gov.sk. ca/Default.aspx? DN=3978 bcd-7dfa-4a 47-8ab7043419 efecd5. Accessed November 22, 2012

Klümper W, Qaim M (2014) A meta-analysis of the impacts of genetically modified crops. Plos One 9:e111629

Korres NE, Norsworthy JK (2015) Influence of a rye cover crop on the critical period for weed control in cotton. Weed Sci 63:346-352

LeBaron HM (2008) Distribution and management of triazineresistant weeds. Pages 119-132 in LeBaron HM, McFarland JE, Burnside OC, eds. The Triazine Herbicides: 50 Years Revolutionizing Agriculture. San Diego, CA: Elsevier

Liebman M, Gallandt ER (1997) Many little hammers: ecological approaches for management of crop-weed interactions. Pages 291-343 in Jackson LE, ed. Ecology in Agriculture. San Diego, CA: Academic Press

Liebman M, Gibson LR, Sundberg DN, Heggenstaller AH, Westerman PR, Chase CA, Hartzler RG, Menalled FD, Davis AS, Dixon PM (2008) Agronomic and economic performance characteristics of conventional and low-external-input cropping systems in the central corn belt. Agron J 100:600-610

Llewellyn RS, Lindner RK, Pannell DJ, Powles SB (2004) Grain grower perceptions and use of integrated weed management. Aust J Exp Agric 44:993-1001

Longchamps L, Panneton B, Simard M-J, Leroux GD (2012) Could weed sensing in corn inter-rows result in efficient weed control? Weed Technol 26:649-656

Lovely WG, Weber CR, Staniforth DW (1958) Effectiveness of the rotary hoe for weed control in soybeans. Agron J 50:621625

Manalil S, Busi R, Renton M, Powles SB (2011) Rapid evolution of herbicide resistance by low herbicide dosages. Weed Sci 59:210-217

Manalil S, Renton M, Diggle A, Busi R, Powles SB (2012) Simulation modelling identifies polygenic basis of herbicide resistance in a weed population and predicts rapid evolution of herbicide resistance at low herbicide rates. Crop Prot 40:114120

McElroy JS (2014) Vavilovian mimicry: Nikolai Vavilov and his little-known impact on weed science. Weed Sci 62:207-216

582 - Weed Science 64, Special Issue 2016 
McMullan PM, Green JM (2011) Identification of a tall waterhemp (Amaranthus tuberculatus) biotype resistant to HPPD-inhibiting herbicides, atrazine, and thifensulfuron in Iowa. Weed Technol 25:514-518

Mortensen DA, Egan JF, Maxwell BD, Ryan MR, Smith RG (2012) Navigating a critical juncture for sustainable weed management. BioScience 62:75-84

Norris RF (1999) Ecological implications of using thresholds for weed management. J Crop Prod 2:31-58

Norris RF (2007) Weed fecundity: current status and future needs. Crop Prot 26:182-188

Norsworthy JK, Griffith G, Griffin T, Bagavathiannan M, Gbur EE (2014) In-field movement of glyphosate-resistant Palmer amaranth (Amaranthus palmeri) and its impact on cotton lint yield: evidence supporting a zero-threshold strategy. Weed Sci 62:237-249

Norsworthy JK, Oliveira MJ (2004) Comparison of the critical period for weed control in wide- and narrow-row corn. Weed Sci 52:802-807

Norsworthy JK, Ward SM, Shaw DR, Llewellyn RS, Nichols RL, Webster TM, Bradley KW, Frisvold G, Powles SB, Burgos NR, Witt WW, Barrett M (2012) Reducing the risks of herbicide resistance: best management practices and recommendations. Weed Sci 60:31-62

Oerke EC (2006) Crop losses to pests. J Agr Sci 144:31-43

Owen MDK (1997) Risks and benefits of weed management technologies. Pages 291-297 in De Prado R, Jorrin J, GarciaTorres L, eds. Weed and Crop Resistance to Herbicides. London: Kluwer Academic Publishers

Owen MDK (2001) World maize/soybean and herbicide resistance. Pages 101-163 in Powles SB, Shaner DL, eds. Herbicide Resistance and World Grains. Boca Raton: CRC Press

Owen MDK (2008) Weed species shifts in glyphosate-resistant crops. Pest Manag Sci 64:377-387

Owen MDK (2012) Herbicide resistance in weeds: What is nature of the problem? Pages 3-4 in Proceedings of the National Summit on Strategies to Manage Herbicide-Resistant Weeds. Washington, DC: National Academies Press

Owen MDK (2013) Pest resistance: overall principles and implications on evolved herbicide resistance in Iowa. Pages 125-136 in Pringnitz B, ed. Proceedings of the 2013 Integrated Crop Management Conference. Ames, IA: Iowa State University

Owen MDK, Beckie HJ, Leeson JY, Norsworthy JK, Steckel LE (2015) Integrated pest management and weed management in the United States and Canada. Pest Manag Sci 71:357-376

Patzoldt WL, Tranel PJ, Hagar AG (2005) A waterhemp (Amaranthus tuberculatus) biotype with multiple resistance across three herbicide sites of action. Weed Sci 53:30-36

Peteinatos GG, Weis M, Andujar D, Rueda V, Gerhards A, Gerhards 1 (2014) Potential use of ground-based sensor technologies for weed detection. Pest Manag Sci 70:190-199

Pichancourt J-B, van Klinken RD (2012) Phenotypic plasticity influences the size, shape and dynamics of the geographic distribution of an invasive plant. Plos One 7:e32323

Powles SB (2008) Evolved glyphosate-resistant weeds around the world: lessons to be learnt. Pest Manag Sci 64:360-365

Prince JM, Shaw DR, Givens WA, Newman ME, Owen MDK, Weller SC, Young BG, Wilson RG, Jordan DL (2012) Benchmark Study: III. Survey on changing herbicide use patterns in glyphosate-resistant cropping systems. Weed Technol 26:536-542
Prokopy LS, Floress K, Klotthor-Weinkauf D, Baumgart-Getz A (2008) Determinants of agricultural best management practice adoption: evidence from the literature. J Soil Water Conserv 63:300-311

Reimer AP, Thompson AW, Prokopy LS (2012) The multidimensional nature of environmental attitudes among farmers in Indiana: implications for conservation adoption. Agric Hum Values 29:29-40

Riar DS, Norsworthy JK, Steckel LE, Stephenson DO IV, Eubank, TW, Bond J, Scott RC (2013) Adoption of best management practices for herbicide-resistant weeds in midsouthern United States cotton, rice, and soybean. Weed Technol 27:788-797

Rich AM, Renner KA (2007) Row spacing and seeding rate effects on eastern black nightshade (Solanum ptycanthum) and soybean. Weed Technol 21:124-130

Sayer J, Sunderland T, Ghazoul J, Pfund J-L, Sheil D, Meijaard E, Venter M, Boedhihartono AK, Day M, Garcia C, van Oosen C, Buck LE (2013) Ten principles for a landscape approach to reconciling agriculture, conservation, and other competing land uses. Proc Natl Acad Sci USA 110:8349-8356

Shaner DL (2014) Lessons learned from the history of herbicide resistance. Weed Sci 62:427-431

Sosnoskie LM, Culpepper S (2013) Deep Tillage and Cover Crops for Palmer Amaranth. Davis, CA: University of California Davis. 3 p. http://ucanr.edu/blogs/blogcore/ postdetail.cfm?postnum=10319. Accessed February 25, 2016

Stern VM, Smith RF, van den Bosch R, Hagen KS (1959) The integrated control concept. Hilgardia 29:81-101

Swanton CJ, Mahoney KJ, Chandler K, Gulden RH (2008) Integrated weed management: knowledge-based weed management systems. Weed Sci 56:168-172

Swanton CJ, Murphy SD (1996) Weed science beyond the weeds: the role of integrated weed management (IWM) in agroecosystem health. Weed Sci 44:437-445

Swanton CJ, Weise SF (1991) Integrated weed management: the rationale and approach. Weed Technol 5:648-656

Switon SM (2005) Economics of site-specific weed management. Weed Sci 53:259-263

Thill DC, Lish JM, Callihan RH, Bechinski EJ (1991) Integrated weed management-a component of integrated pest management: a critical review. Weed Technol 5:648-656

Tranel PJ, Wright TR (2002) Resistance of weeds to ALSinhibiting herbicides: what have we learned? Weed Sci 50:700-712

Ulloa SM, Datta A, Malidza G, Leskovsek R, Knezevic SZ (2010) Timing and propane dose of broadcast flaming to control weed population influenced yield of sweet maize (Zea mays L. var. rugosa). Field Crop Res 118:282-288

VanGessel MJ (2001) Glyphosate-resistant horseweed from Delaware. Weed Science 49:703-705

Vasileiadis VP, Moonen AC, Sattin M, Otto S, Pons X, Kudsk P, Veres A, Dorner Z, van der Weide R, Marraccini E, Plelzer E, Angevin F, Kiss J (2013) Sustainability of European maizebased cropping systems: economic, environmental and social assessment of current and proposed innovative IPM-based systems. Eur J Agron 48:1-11

Vasileiadis VP, Otto S, van Dijk W, Urek G, Leskovsek R, Verschwele A, Furlan L, Sattin M (2015) On-farm evaluation of integrated weed management tools for maize production in three different agro-environments in Europe: agronomic efficacy, herbicide use reduction, and economic sustainability. Eur J Agron 63:71-78

Owen: Herbicide-resistant weed management • 583 
Vencill WK, Nichols RL, Webster TM, Soteres JK, MallorySmith C, Burgos NR, Johnson WG, McClelland MR (2012) Herbicide resistance: toward an understanding of resistance development and the impact of herbicide-resistant crops. Weed Sci 60:2-30

Vigueira CC, Olsen KM, Caicedo AL (2013) The red queen in corn: agricultural weeds as models of rapid adaptive evolution. Heredity 110:303-311

Walker RH, Buchanan GA (1982) Crop manipulation in integrated weed management systems. Weed Sci 30:17-24

Walsh MJ, Harrington RB, Powles SB (2012) Harrington seed destructor: a new nonchemical weed control tool for global grain crops. Crop Sci 52:1343-1347

Ward SM, Cousens RD, Bagavathiannan MV, Barney JN, Beckie HJ, Busi R, Davis AS, Dukes JS, Forcella F, Freckleton RP, Gallandt ER, Hall LM, Jasieniuk M, Lawton-Rauh A, Lehnhoff EA, Liebman M, Maxwell BD, Mesgaran MB, Murray JV, Neve P, Nuñez MA, Pauchard A, Queenborough SA, Webber BL (2014) Agricultural weed research: a critique and two proposals. Weed Sci 62:672-678

Weersink A, Llewelln RS, Pannell DJ (2005) Economics of preemptive management to avoid weed resistance to glyphosate in Australia. Crop Prot 24:659-665

Wilson RS, Tucker MA, Hooker NH, LeJeune JT, Doohan D (2008) Perceptions and beliefs about weed management: perspectives of Ohio grain and produce farmers. Weed Technol 22:339-350

Wooton EO (1894) New Mexico Weeds. New Mexico College of Agriculture and the Mechanical Arts. Bulletin No. 1. Las Cruces, NM: Agricultural Experiment Station. $46 \mathrm{p}$

Wurtz TL (1995) Domestic geese: biological weed control in an agricultural setting. Ecol Appl 5:570-578

Young BG (2006) Changes in herbicide use patterns and production practices resulting from glyphosate-resistant crops. Weed Technol 20:301-307

Young SL (2012) True integrated weed management. Weed Res 52:107-111

Young SL, Pierce FJ (2014) Automation: The Future of Weed Control in Cropping Systems. New York: Springer. $265 \mathrm{p}$

Zalucki MP, Furlong MJ, Schellhorn NA, Macfadyen S, Davies AP (2015) Assessing the impact of natural enemies in agroecosystems: toward "real" IPM or in quest of the Holy Grail? Insect Sci 22:1-5

Received July 18, 2015, and approved January 2, 2016.

Associate Editor for this paper: Sarah Ward, Colorado State University. 